\title{
NGEMPLAK SUTAN SEBAGAI KAMPUNG ZERO WASTE DI SURAKARTA
}

\author{
Shinta Ahdiani Zulfa' ${ }^{1}$ Paramita Rahayu'1 ${ }^{1}$ Erma Fitria Rini ${ }^{1}$ \\ ${ }^{1}$ Program Studi Perencanaan Wilayah dan Kota, Fakultas Teknik, Universitas Sebelas Maret
}

\begin{abstract}
Abstrak
Permasalahan persampahan terutama dalam hal volume harian sampah yang sangat besar di Indonesia dipengaruhi oleh kondisi masyarakat yang masih menganut paradigma lama persampahan, yaitu kumpul, angkut, buang. Konsep zero waste menjadi solusi bagi kawasan yang ingin mengatasi masalah persampahan. Surakarta dengan produksi sampah mencapai 310 ton perhari menggagas solusi yang salah satunya dengan membentuk kampung yang menerapkan pengelolaan sampah dari sumber yang diimplementasikan pada Kampung Ngemplak Sutan RW 37, Mojosongo. Tujuan dari penelitian ini adalah untuk mengevaluasi sejauh mana dan bagaimana penerapan konsep zero waste di Kampung Ngemplak Sutan. Pendekatan yang digunakan adalah pendekatan deduktif dengan metode penelitian kuantitatif. Teknik analisis yang digunakan adalah teknik analisis skoring dengan skala likert dan statistik deskriptif. Teknik analisis skoring dengan skala likert pada penelitian ini dilakukan untuk melakukan evaluasi yang didasarkan pada persepsi masyarakat yang kemudian dituangkan dalam skala penilaian. Hasil skoring likert berupa persentase pencapaian dari masing-masing komponen. Analisis deskriptif digunakan untuk memperkaya informasi dari analisis skoring likert. Secara keseluruhan, hasil analisis menunjukkan bahwa Kampung Ngemplak Sutan telah menerapkan konsep zero waste dengan persentase realisasi $67,78 \%$ dan masuk dalam range penilaian baik. Komponen yang paling memberikan pengaruh pada capaian persentase tersebut adalah infrastruktur (34.7\%), sumber daya manusia/SDM (16.73\%), dan kebijakan (13.64\%). Oleh karena itu, dapat dikatakan bahwa infrastruktur, SDM, dan kebijakan merupakan tiga komponen penting yang harus diperhatikan dalam upaya menerapkan konsep zero waste di suatu lingkungan. Disamping itu, sub komponen lain seperti potensi ekonomi dan kelembagan juga penting untuk dipertimbangkan karena secara keseluruhan semua komponen tersebut akan mempengaruhi keberhasilan penerapan konsep zero waste.
\end{abstract}

Kata kunci: kampung minim sampah; konsep zero waste; penilaian; Surakarta

\begin{abstract}
Exaggerated volume of waste that cause waste problems in Indonesia is affected by many factors, among others is the old paradigm of waste, namely gathering, transporting, and disposing. Regarding this problem, the new paradigm of managing waste, the concept of zero waste can be a solution offered to regions that want to overcome the problem of exaggerated volume of waste. Surakarta, with 310 tons of waste production in a day, has tried to come up with a solution to overcome the problem of waste they produce, one of which is by establishing a pilot project of a village that implements waste management from its source. The village isNgemplak Sutan RW 37, Mojosongo. The purpose of this study is to evaluate the extent to which and how the application of the concept of zero waste is conducted in Ngemplak Sutan. The research applies quantitative research methods withLikert Scale and statistical descriptive analysis. Likert Scaleapplied in this study to evaluate community's perception which is outlined in the rating scale. The likert results is in the form of a percentage of achievement of each component based on the perceptions. Statistical descriptive is impelented to enrich information from Likert Scale analysis. The result shows that the implementation concept of Zero waste in Ngemplak Sutan village has achieved about $67.78 \%$ of the entire components of zero waste concept. This percentage is considered good. The most affected components are infrastructure (34.78\%), human resources (16.73\%)., and policy (13.64\%). Therefore, infrastructure, human resources, and policies are three important components that must be considered to start the implementationof the zero waste concept of . In addition to that, it is also important to consider other components such as economic and institutionalcomponents, because both of these components will also affect the successful implementation of zero waste.
\end{abstract}

Keywords: assessment; Surakarta; zero waste concept; zero waste kampong 


\section{PENDAHULUAN}

Kota dengan segala aktivitas baik pendidikan, kesehatan, perekonomian, sosial dsb. tentunya tidak bisa dipungkiri adanya penciptaan zat sisa/ buangan yang volumenya juga tidaklah sedikit karena intensitas aktivitas juga dilakukan setiap saat tanpa henti. Africa (2010) dalam Nizar (2017) menyatakan bahwa di berbagai wilayah perkotaan di Indonesia pengelolaan sampah merupakan salah satu isu yang menjadi perhatian utama. Kualitas pelayanan sampah menjadi salah satu indikator bagusnya tata kelola pemerintahan kota. Pemerintah melalui Dinas Kebersihan dan Pertamanan atau Dinas Lingkungan Hidup harus bekerja ekstra untuk bisa mengelola volume sampah yang terus naik setiap tahunnya.

Konsep pengembangan untuk mengatasi permasalahan persampahan mulai muncul. Konsep tersebut disebut dengan konsep zero waste. Alangkah baiknya apabila konsep zero waste ini dimulai dari skala terkecil masyarakat perkotaan. Skala keluarga atau rumah tangga merupakan prioritas utama kemudian berlanjut pada skala Rukun Tetangga dan Rukun Warga. Sebisa mungkin dari skala terkecil sudah mampu mengurangi timbulan sampah yang akan diangkut ke TPA atau bahkan menjadikannya pada angka 0 sehingga membuat masa pakai TPA juga semakin panjang.

Menurut Kasi Pengelolaan Sampah DLH dalam Andimuhtarom (2017), volume sampah rata-rata Surakarta dari tahun 2015 tercatat 275 ton perhari, 2016 tercatat 298 ton per hari dan tahun 2017310 ton perhari. Tren dari volume sampah di Kota Surakarta terus mengalami kenaikan dari tahun ke tahun. Apabila kenaikan itu terjadi terus-menerus, maka bukan tidak mungkin TPA yang disediakan tidak mampu lagi menampung timbunan sampah untuk beberapa tahun kedepan. Kasi Pengelolaan Sampah Dinas Kebersihan dan Pertamanan (DKP) Solo, Muhammad Pramudjo dalam Abriyani (2016) menjelaskan bahwa lahan TPA Putri Cempo memiliki luas 17 hektar dengan masa pakai 20 tahun. Namun faktanya TPA Putri Cempo sampai tahun 2019 telah digunakan selama 30 tahun.

Penerapan konsep zero waste mulai diinisiasi oleh RW 37 Kampung Ngemplak Sutan, Kelurahan Mojosongo, Surakarta. Kampung ini disebut juga sebagai kampung organik. Sebutan ini disematkan karena kampung ini berusaha untuk memanfaatkan lahan yang ada (RTH) untuk ruang penanaman sayur-mayur dan membudidayakannya menggunakan teknik vertikultur. Mereka mengembangkan sistem pengolahan persampahan yang terintegrasi, yaitu mencoba mengintegrasikan antara pegelolaan sampah, peningkatan/pemberdayaan masyarakat, dan peningkatan taraf kehidupan masyarakat. Sedangkan, masih banyak wilayah yang mengalami masalah pengelolaan sampah dan belum berhasil mengatasinya. Dalam penerapan zero waste yang berkelanjutan juga diperlukan adanya kepedulian dari masyarakat dalam menjalankannya dan mengelolanya dengan sumber daya yang ada. Fakta-fakta permasalahan persampahan tersebut membuat peneliti ingin melihat fenomena kampung yang sudah berusaha menerapkan konsep minim sampah (zero waste) di Kota Surakarta, yaitu Kampung Ngemplak Sutan. Maka dari itu muncul pertanyaan penelitian, yaitu bagaimana penerapan konsep minim sampah (zero waste) di Kampung Ngemplak Sutan RW 37, Mojosongo dalam pelaksanaanya selama kurang lebih lima tahun ini. Peneiliti ingin mengevaluasi penerapan konsep zero waste dengan cara mengidentifikasi tiap komponen zero waste di Kampung Ngemplak Sutan kemudian dievaluasi berdasarkan persepsi masyarakat selaku subyek pelaksana dari konsep zero waste. Maka dari hasil penilaian persepsi yang kemudian didukung deskripsi dari hasil identifikasi dapat menjelaskan sejauh mana pelaksanaan konsep zero waste di Kampung Ngemplak Sutan.

\section{KAJIAN PUSTAKA}

Konsep zero waste merupakan konsep ideal suatu kota dalam hal pengelolaan persampahan dimana seluruh elemen kota baik itu masyarakat, pemerintah maupun pelaku usaha harus meminimalkan produksi sampah dan menekan dampak buruk sampah terhadap lingkungan dengan cara-cara yang berwawasan lingkungan. Upaya yang dapat dilakukan beragam mulai dari daur ulang sampah organik dalam bentuk kegiatan komposting, daur ulang sampah anorganik berupa kegiatan penjualan ke informal collector dan pembuatan kerajinan, dan membentuk komunitas peduli lingkungan (Zero Waste Alliance dan Connett dalam Nizar, 2017).

Zaman (2013) berargumen bahwa terdapat lima komponen/variabel yang menjadi tolak ukur keberhasilan pelaksanaan konsep zero waste di suatu kawasan. Kelima komponen tersebut, yaitu policy (kebijakan), socio-culture (sosio-kultural), waste management (manajemen pengelolaan sampah), government and infrastructure (pemerintah dan infrastruktur), dan market 
creation (penciptaan pasar). Kemudian setiap variabel dipahami dalam konteks lokal di Indonesia dengan penjabaran sebagai berikut.

\subsection{REGULATORY POLICIES AND WASTE MANAGEMENT DEVELOPMENT DRIVERS (KEBIJAKAN DAN FAKTOR KUNCI PENGEMBANGAN MANAJEMEN PERSAMPAHAN)}

Hukum merupakan alat yang digunakan untuk menciptakan keadilan dan menjunjung tinggi kebenaran. Hukum juga bersifat mengontrol perilaku masyarakat agar tetap sesuai dengan nilai dan norma yang dianut di suatu kawasan. Penegakan terhadap hukum yang berlaku dipengaruhi oleh faktor-faktor, yaitu peraturan yang dilegalkan, penegak hukum, sarana penegakan hukum, kepatuhan masyarakat, dan budaya (kebiasaan) masyarakat (Soekanto, 1983).

Namun dalam hal penegakan hukum lingkungan, menurut Mukhlis dan Mustafa Luthfi (2010) dapat dilakukan melalui dua cara, yaitu cara represif dan preventif. Cara represif adalah dengan menggunakan sanksi administratif bagi pelanggar peraturan sedangkan cara preventif lebih kepada membangun kesadaran dengan diberikan wadah dan sarana untuk pelaksanaan program dan aturan yang sudah disepakati.

Waste management development driver dimaknai sebagai tonggak kunci yang diambil oleh pemerintah untuk mewujudkan konsep zero waste. Tonggak kunci ini dapat berupa kebijakan atau strategi yang dijadikan patokan untuk mencapai konsep zero waste secara bertahap dalam kurun waktu tertentu (Zaman, 2013).

\subsection{SOCIO-CULTURE (SOSIO-KULTURAL MASYARAKAT)}

Sosio-kultural berkaitan dengan kondisi masyarakat (sikap, budaya, kondisi sosial) yang sifatnya bisa mendukung atau menghambat zero waste. Kondisi sosio-kultural masyarakat ini biasa dikenal dengan sumber daya manusia. Kondisi sosiokultural masyarakat sangat dipengaruhi oleh pendidikan/edukasi mengenai persampahan yang diterima masyarakat dan kesadaran masyarakat akan pentingnya pengelolaan sampah untuk mencapai zero waste. Upaya menanamkan pendidikan dan kesadaran dapat dilakukan melalui sosialisasi, pelatihan, dan pemberdayaan masyarakat (Zaman, 2014; Suyanto, 2015)

\subsection{WASTE MANAGEMENT (MANAJEMEN PERSAMPAHAN)}

\subsubsection{Product Design}

Desain produk sampah merupakan kegiatan olah ide kreativitas dan seni dengan memanfaatkan material sampah yang bertujuan untuk menaikkan nilai bagi material sampah tersebut. Perlakuan untuk merancang desain produk berbeda untuk jenis sampah organik dan anorganik (Palgunadi, 2008; Wahmuda, 2015).

\subsubsection{Waste Generation and Composition (Volume dan Komposisi Sampah)}

Volume dan komposisi sampah merupakan indikator dalam kesuksesan pelaksanaan konsep zero waste dan juga sebagai bahan untuk penggalian potensi ekonomi dari material sampah. Komposisi akan sangat mempengaruhi tindakan bagi setiap jenis material sampah (Sejati, 2009; Suprapto, 2016).

\subsubsection{Waste Collecting and Recycling (Pengumpulan dan Daur Ulang Sampah)}

SNI Nomor 2454 Tahun 2002 tentang Tata Cara Operasional Pengelolaan Sampah menjabarkan tentang pola pengumpulan sampah kawasan. Pola individual langsung dilakukan oleh petugas kebersihan dengan mendatangi sumber sampah dan langsung diangkut ke TPA. Pola individual tidak langsung adalah pengumpulan sampah yang dilakukan warga atau petugas kebersihan dengan mendatangi sumber sampah kemudian diangkut ke TPS sebelum akhirnya dibuang ke TPA. Pola komunal langsung, yaitu dilakukan pengangkutan menggunakan becak sampah dari wadah komunal lalu dibawa ke kontainer truk ataupun dump truk sampah. Pola pengumpulan sampah komunal tidak langsung dilakukan oleh masing-masing penghasil/sumber sampah lalu dibuang ke TPS atau truk sampah yang sudah disediakan yang kemudian diangkut ke TPA. 


\subsubsection{Waste Avoidance and Reduction (Penghindaran dan Pengurangan Sampah)}

Penghindaran dan pengurangan sampah merupakan upaya masyarakat untuk mengurangi sampah yang diangkut oleh petugas sampah. Upaya tersebut dapat dilakukan saat sebelum mengkonsumsi barang tertentu atau setelah mengkonsumsi barang tertentu (Damanhuri, dkk, 2010).

\subsection{GOVERNMENT AND INFRASTRUCTURE (PEMERINTAH DAN INFRASTRUKTUR)}

\subsubsection{Government (Pemerintah)}

Pemerintah sebagai pemangku kebijakan punya wewenang dan kewajiban dalam merubah masyarakat untuk lebih peduli pada masalah persampahan. Dukungan berupa pelayanan akan pengelolaan sampah dan juga fasilitas pengolaahan sampah juga harus disediakan oleh pemerintah baik pemerintah pusat maupun setempat. Pemerintah melalui kebijakannya juga diharapkan dapat mendorong keterlibatan aktif dari masyarakat dalam mengelola sampah (Mulasari,dkk., 2014).

\subsubsection{Greenwaste Community (Komunitas Masyarakat yang Berdasarkan pada Pusat Daur Ulang)}

Komunitas internal masyarakat yang menjadi penggerak pengelolaan sampah merupakan kontrol terdekat bagi kegiatan pengelolaan sampah di kawasan. Maka dari itu, perlu selalu dijaga dan dikuatkan peran dari komunitas pengelola dan peduli sampah kawasan (Kholil, 2009)

\subsubsection{Infrastructure (Fasilitas Pemilah, Pengumpul, Daur Ulang, Pengangkut, dan Pembuangan Sampah)}

Spesifikasi peralatan persampahan yang idealnya disediakan di lingkungan permukiman menurut SNI Nomor 3242 Tahun 2008 tentang Pengelolaan Sampah dan SNI nomor 2454 tahun 2002 sebagai berikut (Tabel 1).

Tabel 1. Spesifikasi Peralatan Persampahan

\begin{tabular}{|c|c|c|c|c|c|}
\hline \multirow{2}{*}{ No } & \multirow{2}{*}{ Jenis peralatan } & \multicolumn{3}{|c|}{ Kapasitas pelayanan } & \multirow{2}{*}{ Keterangan } \\
\hline & & Volume & KK & Jiwa & \\
\hline 1. & $\begin{array}{l}\text { Wadah individual } \\
\text { (organik-anorganik) }\end{array}$ & $\begin{array}{l}\text { 10-40L } \\
\text { (kantong } \\
\text { plastik) } \\
40 \mathrm{~L} \text { (tong) }\end{array}$ & 1 & $\begin{array}{l}\text { Disediakan } \\
2 \text { buah } \\
\text { wadah } \\
\text { untuk setiap } \\
\text { hunian }\end{array}$ & $\begin{array}{l}\text { Di tempatkan di halaman muka } \\
\text { Wadah harus bersifat tidak mudah rusak, kedap air, ekonomis, } \\
\text { dan mudah dikosongkan } \\
\text { Sampah organik menggunakan wadah warna gelap } \\
\text { Sampah anorganik menggunakan wadah terang } \\
\text { Dapat berbentuk kotak, silinder, kontainer, tong, dan kantong } \\
\text { plastik }\end{array}$ \\
\hline 2. & Wadah komunal & $0,5-1 \mathrm{~m}^{3}$ & $20-40$ & $100-200$ & $\begin{array}{l}\text { Lokasinya sedekat mungkin dengan sumber sampah, tidak } \\
\text { mengganggu pemakai jalan atau sarana lain, di luar jalur lalu } \\
\text { lintas, dan diletakkan di ujung gang kecil. } \\
\text { Sifat wadah tertutup, ringan, mudah dikosongkan, penyediaan } \\
\text { dilakukan oleh instansi pengelola. } \\
\text { Dapat berbentuk kotak, silinder, kontainer, tong }\end{array}$ \\
\hline 3. & $\begin{array}{l}\text { Komposter Individu } \\
\text { Komposter aerob }\end{array}$ & 120 liter & $\begin{array}{l}1 \text { hunian } 1 \\
\text { komposter }\end{array}$ & - & Berupa tong plastik yang dilengkapi pipa vertikal dan horizontal \\
\hline 4. & $\begin{array}{l}\text { Komposter komunal } \\
\text { skala lingkungan }\end{array}$ & $0,5-1 \mathrm{~m}^{3}$ & $10-20$ & $50-100$ & $\begin{array}{l}\text { Pencacahan sampah organik secara konvensional atau dengan } \\
\text { mesin }\end{array}$ \\
\hline 5. & $\begin{array}{l}\text { Alat pengumpul: } \\
\text { gerobak sampah } \\
\text { bersekat/ sejenisnya }\end{array}$ & $\begin{array}{c}1 \mathrm{~m}^{31} \\
\text { Ukuran } \\
0,7 \mathrm{x} 1,5 \mathrm{x} \\
0.6 \mathrm{~m}\end{array}$ & 128 & 640 & $\begin{array}{l}\text { Terbuat dari konstruksi kayu atau pelat besi } \\
\text { Ukuran disesuaikan dengan jalan perumahan } \\
\text { Gerobak sampah bisa disekat menjadi dua bagian untuk } \\
\text { sampah organik dan anorganik }\end{array}$ \\
\hline 6. & $\begin{array}{l}\text { Bangunan pendaur } \\
\text { ulang sampah skala } \\
\text { lingkungan }\end{array}$ & $150 \mathrm{~m}^{2}$ & 600 & 3000 & $\begin{array}{l}2 \text { bangunan yaitu Bank Sampah Karunia dan Amanah. Bank } \\
\text { Sampah Karunia sudah memiliki bangunan tersendiri. } \\
\text { Sedangkan Bank Sampah Amanah memanfaatkan rumah } \\
\text { warga. }\end{array}$ \\
\hline
\end{tabular}

Sumber: SNI Nomor 3242 Tahun 2008, SNI Nomor 2454 Tahun 2002 dan modul sampah 3R 


\subsection{PENCIPTAAN PASAR}

Pemanfaatan sampah sebagai barang bernilai ekonomi sebenarnya harus dilakukan untuk semua kawasan bahkan dalam skala perkotaan. Potensi daur ulang, industri kreatif, dan potensi penjualan langsung ke informal collector merupakan 3 opsi yang dapat dipilih masyarakat. Untuk membuka peluang tersebut masyarakat harus diwadahi baik dalam bentuk fasilitas, keilmuan, dan akses dalam memasarkan barang/jasa yang ditawarkan.(Suprapto, 2016; Krisnani, dkk, 2017).

\section{METODE PENELITIAN}

Metode penelitian yang digunakan adalah metode kuantitatif. Metode kuantitatif merupakan cara mengolah dan meneliti sebuah fenomena yang diterjemahkan serta disajikan ke dalam bentuk data dan fakta numerik. Penelitian yang akan dilakukan bukan bersifat keseluruhan angka, namun peneliti berusaha mengubah data kualitatif menjadi data kuantitatif/dikuantitatifkan agar didapatkan hasil yang sesuai dengan tujuan penelitian. Maka dari itu, penelitian ini merupakan penelitian kuantitatif yang pembahasannya akan dilengkapi dengan penggambaran deskriptif dari hasil teknik analisis deskriptif. Variabel yang dianalisis terdiri dari lima variabel dengan penjabaran dalam Tabel 2 di bawah ini.

Tabel 2. Variabel Penelitian

\begin{tabular}{|c|c|c|}
\hline Variabel & Sub variabel & Parameter \\
\hline Policy (kebijakan) & Kebijakan pengelolaan sampah & Kepatuhan masyarakat pada kebijakan persampahan \\
\hline \multirow{2}{*}{$\begin{array}{l}\text { Socio-culture (sosio- } \\
\text { kultural masyarakat) }\end{array}$} & Edukasi & Efektivitas edukasi masyarakat \\
\hline & Kesadaran & $\begin{array}{l}\text { Kepahaman masyarakat pentingnya pengelolaan } \\
\text { sampah }\end{array}$ \\
\hline \multirow{4}{*}{$\begin{array}{l}\text { Waste Management } \\
\text { (manajemen } \\
\text { persampahan) }\end{array}$} & Desai & $\begin{array}{l}\text { Efektivitas pelaksanaan kegiatan desain produk } \\
\text { sampah }\end{array}$ \\
\hline & an komp & Volume yang tereduksi \\
\hline & Penghindaran dan $\mathrm{p}$ & $\begin{array}{l}\text { Efektivitas pelaksanaan kegiatan penghindaran dan } \\
\text { daur ulang }\end{array}$ \\
\hline & Pengumpulan sampah dan daur ulang & $\begin{array}{l}\text { Efektivitas pelaksanaan kegiatan pengumpulan dan } \\
\text { daur ulang }\end{array}$ \\
\hline \multirow{2}{*}{$\begin{array}{l}\text { Government } \\
\text { Infrastructure }\end{array}$} & Pemerintah & Kontribusi pemerintah lokal \\
\hline & $\begin{array}{l}\text { Organisasi/ komunitas lokal } \\
\text { Infrastruktur }\end{array}$ & $\begin{array}{l}\text { Kontribusi organisasi lokal } \\
\text { Ketersediaan infrastruktur sesuai dengan standar } \\
\text { penyediaan }\end{array}$ \\
\hline $\begin{array}{l}\text { Market creation } \\
\text { (penciptaan pasar) }\end{array}$ & $\begin{array}{l}\text { Pendapatan masyarakat } \\
\text { Ekonomi lokal masyarakat }\end{array}$ & $\begin{array}{l}\text { Peningkatan nilai ekonomi sampah } \\
\text { Pertumbuhan usaha lokal pengelolaan sampah }\end{array}$ \\
\hline
\end{tabular}

Teknik pengumpulan data menggunakan teknik pengumpulan data primer. Teknik pengumpulan data primer merupakan pengumpulan data yang dilakukan dengan mencari data dari sumbernya langsung, bukan dari pihak kedua maupun ketiga untuk mengetahui fakta-fakta di lapangan. Instrumen yang digunakan untuk pengumpulan data, yaitu berupa kuesioner, wawancara, dan observasi (Tabel 3). Responden dari penelitian merupakan warga Ngemplak Sutan dan pengurus setempat. Jumlah total populasi, yaitu 800 penduduk. Jumlah sampel responden penelitian dihitung menggunakan rumus slovin. Rumus slovin adalah rumus yang digunakan untuk mengetahui jumlah sampel minimal apabila perilaku dari populasi tidak diketahui. Rumus slovin juga biasa digunakan untuk menghitung jumlah sampel yang terlalu banyak, sehingga sampel yang didapatkan lebih sedikit namun tetap dapat mewakili populasi yang besar.

$$
\mathrm{n}=\frac{N}{1+N \cdot d 2}
$$

dimana :

$\mathrm{n}=$ Jumlah sampel

$\mathrm{N}=$ Jumlah populasi

$d=$ Tingkat kesalahan maksimum pengambilan sampel $10 \%(0,01)$ 
Tabel 3. Sampel Penelitian

\begin{tabular}{lll}
\hline \multicolumn{1}{c}{ Komponen Masyarakat RW 37 } & \multicolumn{1}{c}{ Teknik pengumpulan data } & \multicolumn{1}{c}{ Proporsi sampel } \\
\hline Masyarakat umum & Kuesioner & RT 01 sampelnya 21 orang \\
(dihitung dari rumus slovin) & & RT 02 sampelnya 21 orang \\
& & RT 03 sampelnya 42 orang \\
Petugas sampah & Wawancara & (total petugas jadi sampel penelitian) \\
Pengurus pemerintahan setempat & Wawancara & (total pengurus pemerintahan jadi sampel \\
& & penelitian) \\
\hline
\end{tabular}

Teknik analisis yang digunakan, yaitu analisis skoring likert dan analisis deskriptif. Teknik analisis skoring likert menggunakan instrumen kuesioner yang berisi pertanyaan yang berkaitan dengan komponen konsep zero waste yang juga diturunkan dari teori-teori zero waste. Opsi jawaban yang disajikan dalam skala penilaian, yaitu dari sangat tidak baik sampai sangat baik. Kemudian untuk perhitungan persentase tiap variabel/ komponen dilakukan dengan cara menjumlahkan skor untuk masing-masing variabel lalu dibagi total skor semua variabel dikalikan seratus persen.

Teknik analisis deskriptif normatif merupakan teknik analisis yang digunakan untuk mengidentifikasi dan menjabarkan informasi yang belum didapatkan pada analisis likert. Data-data diambil menggunakan proses wawancara dan observasi. Narasumber ada 3 yaitu dari pengurus komunitas, pengelola pemerintahan setempat, dan petugas sampah.

\section{HASIL DAN PEMBAHASAN}

\subsection{POLICY AND WASTE MANAGEMENT DRIVERS (KEBIJAKAN DAN FAKTOR KUNCI PENGELOLAAN PERSAMPAHAN)}

Kebijakan pengelolaan sampah di kampung Ngemplak Sutan mengikuti kebijakan utama yang ada di Kota Surakarta yaitu Peraturan daerah nomor 3 tahun 2010 tentang Pengelolaan Sampah di Kota Surakarta. Dalam perda tersebut sudah dijabarkan mengenai mekanisme pengelolaan sampah mulai dari skala rumah tangga. Diantaranya ada pengumpulan sampah, pengurangan sampah, pemilahan sampah, dan pengangkutan sampah. Referensi lain, pada buku integrasi data informasi lingkungan DLH (2013) Kota Surakarta dijelaskan mengenai mekanisme pengangkutan sampah yang dapat menjadi opsi bagi suatu kawasan. Peraturan skala kawasan hanya berupa program pengolahan sampah organik dan anorganik berwawasan lingkungan dan program pemilahan sampah. Masyarakat kampung Ngemplak Sutan memberikan penilaian kebijakan dan regulasi di kawasan yaitu sebesar $66,37 \%$ yang masuk dalam range penilaian baik. Persentase pelaksanaan tersebut bisa lebih baik lagi apabila persentase penerapan insentif dan disinsentif di kawasan juga tinggi yang pada hasil analisis hanya menunjukkan angka 31,67\%. Pemerintahan lokal dan komunitas setempat belum merealisasikan insentif dan disinsentif dikarenakan tanggapan masyarakat terhadap pemberlakukan disinsentif khususnya masih kurang baik. Masyarakat cenderung tidak setuju apabila ditetapkan sanksi dan keberadaan sanksi/disinsentif tidak akan berjalan efektif. Hal tersebut dikarenakan untuk penerapan pembuatan kebijakan, penegakkan kebijakan oleh masyarakat dan percontohan oleh pemerintahan setempat berada dalam kelas persentase $60-79 \%$. Kebijakan lokal yang ada di kawasan, yaitu peraturan pemilahan sampah, peraturan pengelolaan sampah organik-anorganik dan peraturan retribusi persampahan. Kebijakan yang telah ditetapkan masih belum sepenuhnya dilaksanakan karena sifat memaksa dan mengikat yang seharusnya dimiliki kebijakan lokal tidak dapat diberlakukan kepada masyarakat.

Waste management drivers atau yang lebih dipahami sebagai faktor/tonggak kunci pendorong keberhasilan penerapan konsep zero waste di Kampung Ngemplak Sutan terbagi berdasarkan tahun pelaksanaannya. Pada tahun 2013, yaitu dimulainya inisiasi program kampung sayur secara mandiri oleh masyarakat yang kemudian dibarengi dengan masuknya kerjasama dengan pihak swasta. Kemudian pada tahun 2014-2016 mulai ada pengadaan infrastruktur persampahan yang disediakan swadaya oleh masyarakat dan bantuan dari pihak lainnya. Kemudian dilanjutkan dengan pembuatan organisasi pengelola sampah organik dan anorganik berupa Bank Sampah yang dikukuhkan melalui SK Walikota dan KSM pengelola sampah.

Apabila dikembalikan ke pertanyaan penelitian, maka komponen kebijakan sudah berjalan dalam beberapa aspek namun belum optimal. Kondisi ketidakoptimalan tersebut didasarkan pada aspek pembuatan aturan insentif dan disinsentif serta penegakkan aturan dan program yang telah ditetapkan. 


\subsection{SOCIO-CULTURAL (SOSIO-KULTURAL MASYARAKAT)}

Dalam membangun sosio-kultural masyarakat harus memperhatikan dua hal penting, yaitu aspek edukasi dan kesadaran masyarakat (Zaman, 2013). Hasil analisis skoring likert edukasi menunjukkan bahwa penerapan sub komponen edukasi sudah berjalan $73,49 \%$. Persentase tersebut masuk dalam range penilaian baik. Hasil wawancara kepada stakeholder setempat menunjukkan bahwa proses edukasi di Kampung Ngemplak Sutan, meliputi proses edukasi pengenalan sampah, pemilahan jenis sampah, edukasi daur ulang sampah anorganik, edukasi komposting sampah organik dan edukasi manajemen organisasi bank sampah. Dengan banyaknya edukasi yang didapatkan masyarakat maka proses pembelajaran dapat dinilai sudah baik dan juga sudah melibatkan banyak instansi di antaranya Rumah Zakat, DLH, dan akademisi.

Sedangkan untuk sub komponen kesadaran, hasil analisis menunjukkan persentase $70,95 \%$ yang berada pada range penilaian baik. Selain itu bila dilihat dari sejarahnya, masyarakat Kampung Ngemplak Sutan sebelum tahun 2013 masih sangat apatis dalam hal pengelolaan sampah sehingga lingkungan permukiman mereka sangat kotor dan berdampak pada kesehatan masyarakat. Namun kemudian sekelompok pemuda Kampung Ngemplak Sutan bekerja sama dengan Rumah Zakat membuat percontohan berupa kegiatan bersih-bersih sampah dan penanaman vegetasi. Kemudian dari Rumah Zakat sendiri memberikan sosialisasi/penyuluhan mengenai pengelolaan sampah dan penjagaan kebersihan lingkungan, barulah warga lainnya melakukan pengelolaan sampah di sekitar hunian mereka sehingga lambat laun kondisi kampung yang tadinya begitu kumuh menjadi lebih sehat. Dari proses tersebut maka dapat disimpulkan bahwa kelompok pemuda yang mengawali pengelolaan sampah memiliki tingkat kesadaran autonomous karena berlandaskan motivasi dari diri sendiri. Sedangkan warga yang lain memiliki tingkat kesadaran yang bersifat sosionomous yaitu berorientasi kepada khalayak ramai. Secara keseluruhan hasil analisis skoring likert untuk komponen sosio kultural, yaitu sebesar $72,47 \%$ yang berada dalam range penilaian baik.

\subsection{WASTE MANAGEMENT (MANAJEMEN PERSAMPAHAN)}

Dalam jurnal Zaman (2013), penelitian yang mengambil tempat di Adelaide tepatnya pada komponen manajemen pengelolaan sampah didetailkan menjadi empat sub komponen, yaitu desain produk sampah, penghindaran dan pengurangan produksi sampah, pengumpulan dan daur ulang sampah serta volume dan komposisi sampah. Sub komponen pertama, yaitu desain produk sampah yang dipahami aktivitas pengembangan bentuk, teknik, proses produksi, dan peningkatan pasar. Hal yang ditekankan pada desain produk, yaitu penggalian ide desain dan inovasi produk dari material sampah (Palgunadi, 2008). Hasil persepsi masyarakat menunjukkan bahwa proses desain produk sudah dilaksanakan $51,19 \%$ dan hasil tersebut masuk dalam range cukup.

Persentase tersebut merepresentasikan kreasi masyarakat dalam mendesain, mencetuskan ide dan kreasi dalam mengolah sampah. Di antara pemanfaatan material sampah yang dipilih masyarakat dari hasil wawancara dan observasi, yaitu pemanfaatan sampah organik sebagai pupuk kompos padat dan pemanfaatan sampah anorganik sebagai kerajinan anyaman untuk taplak dan tikar, kerajinan bunga plastik, dan kerajinan bros bunga. Pemanfaatan sampah anorganik hanya pada berasal dari material sampah plastik kemasan dan sampah plastik kresek. Selain itu, terdapat pula kegiatan pemberdayaan dalam hal desain produk yang dilakukan oleh Dinas Lingkungan Hidup, akademisi, dan agenda kelurahan, yaitu paguyuban sedekah sampah.

Sub komponen kedua adalah waste generation and composition (volume dan komposisi sampah). Volume sampah disini dikaitkan dengan jumlah sampah yang terkelola dari kegiatan manajemen sampah. Volume sampah yang diproduksi oleh RW 37 Kampung Ngemplak Sutan adalah sebanyak 2,8125 m3/ hari. Apabila dirata-rata setiap KK menghasilkan 0,0195 m3/ hari. Sampah tersebut masih tercampur antara sampah organik, sampah anorganik (yang belum dipilah masyarakat) dan sampah residu. Jumlah itu dihitung dari pengangkutan sampah dalam 1 hari, yaitu sebanyak 1-2 kali pengangkutan dalam 1 gerobak sampah. Total volume dan pembagian komposisi sampah di kawasan ditunjukkan dalam Tabel 4.

Volume dan komposisi sampah digunakan sebagai modal untuk penentuan pemanfaatan dan ide desain yang akan diterapkan untuk tiap jenis material (Suprapto, 2016). Volume dan komposisi sampah, yaitu sampah organik sebanyak 35-40 $\mathrm{kg}$ per bulan yang terdiri atas sampah dapur (sayur, buah) dan sampah pohon (dedaunan). Tren di kawasan perkotaan pada umumnya menunjukkan produksi sampah organik lebih banyak dari sampah anorganik. Maka bila dilihat dari tren tersebut, sampah organik yang diangkut di Kampung Ngemplak Sutan hanya sampah dapur dan itupun tidak semua dari warga 
mengumpulkan ke petugas sampah. Ada yang sudah mengolahnya menjadi kompos di rumahnya atau melakukan pembakaran sampah di pekarangan rumah. Volume sampah organik tersebut dapat diolah menjadi pupuk kompos dimana dapat diasumsikan $1 \mathrm{~kg}$ sampah organik dapat menghasilkan 0,6 kg kompos (Purnamayani, 2011). Maka seharusnya Kampung Ngemplak Sutan dapat menghasilkan 24 kg kompos setiap bulannya untuk sekali pemanenan kompos. Kompos yang dihasilkan untuk setiap pemanenan mencapai rata-rata $25 \mathrm{~kg}$ per bulan, dan hasil di lapangan ternyata kurang lebih sama dengan perhitungan produksi. Volume sampah anorganik sejumlah 105,5 kg terhitung yang masuk pada data Bank Sampah Amanah. Sisanya ada pada petugas sampah yang melakukan pemisahan kembali saat pengangkutan sampah.

Tabel 4. Komposisi Sampah Kampung Ngemplak Sutan RW 37, Mojosongo.

\begin{tabular}{|c|c|c|c|}
\hline No & Organik & Non organik & Sampah residu \\
\hline 1. & $\begin{array}{l}\text { Sampah sayuran, buah-buahan, } \\
\text { daun dari pepohonan di } \\
\text { lingkungan permukiman }\end{array}$ & $\begin{array}{l}\text { Koran } \\
\text { Kertas } \\
\text { Kertas putihan/ HVS } \\
\text { Duplex } \\
\text { Kardus } \\
\text { Botol Aqua } \\
\text { Botol Kaca } \\
\text { Botol Putihan } \\
\text { Botol Warna } \\
\text { Kresek } \\
\text { P.E } \\
\text { Recek-recekan } \\
\text { Bak plastik } \\
\text { Tutup galon } \\
\text { Kaleng } \\
\text { Alumunium } \\
\text { Seng } \\
\text { Besi } \\
\text { Karung dll }\end{array}$ & $\begin{array}{l}\text { Kulit buah atau bahan } \\
\text { organik yang tidak dapat } \\
\text { dibuat kompos } \\
\text { Barang-barang elektronik } \\
\text { dan kemasan yang tidak } \\
\text { dapat didaur ulang oleh } \\
\text { warga }\end{array}$ \\
\hline $\begin{array}{l}\text { Rata- } \\
\text { rata } \\
\text { volume }\end{array}$ & $\begin{array}{l} \pm 40 \mathrm{~kg} \\
\text { (yang masuk ke mesin } \\
\text { pencacah kompos) }\end{array}$ & $\pm 105,5 \mathrm{~kg} /$ bulan & - \\
\hline
\end{tabular}

Sub komponen selanjutnya adalah pengumpulan dan daur ulang sampah. Persentase pelaksanaan sub komponen pengumpulan dan daur ulang, yaitu $69,05 \%$ masuk dalam range penilaian baik. Persentase penilaian dapat dijelaskan dari proses pengelolaan persampahan mulai dari pengumpulan sampai daur ulang yang dilaksanakan oleh masyarakat. Pengumpulan di Kampung Ngemplak Sutan menggunakan pola individu langsung dan komunal tidak langsung. Pola pengangkutan tersebut tergantung pada lokasi dari permukiman dan topografi permukiman. Pola individual langsung dilakukan oleh truk sampah dari Dinas Lingkungan Hidup. Pola komunal langsung dilakukan oleh petugas sampah kawasan dan dilakukan sehari sekali. Sebelum diangkut oleh petugas sampah, masyarakat sudah lebih dahulu melakukan pemilahan sampah dan menyisihkan sampah anorganik untuk disetorkan ke bank sampah. Daur ulang sampah anorganik sudah dilakukan oleh masyarakat, namun hanya beberapa orang saja yang merupakan pengurus Bank Sampah Amanah. Produk daur ulang yang dibuat masyarakat berupa taplak meja, karpet, buket bunga, dan bros bunga. Sampah organik didaur ulang menjadi pupuk kompos padat. Proses komposting dilakukan secara komunal dan individu. Dalam proses komposting ini sebelumnya dilakukan pencacahan terhadap sampah organik untuk memudahkan pemadatan sampah dalam tong komposter.

Sub komponen penghindaran dan pengurangan sampah dari hasil analisis menunjukkan persentase pelaksanaan sebesar $66,07 \%$ yang mana masuk dalam range penilaian baik. Bentuk kegiatan penghindaran dan pengurangan sampah yang dilakukan masyarakat Kampung Ngemplak Sutan yang mendukung ketercapaian hasil evaluasi tersebut di antaranya ada penggunaan kantong belanja untuk mengurangi kantong plastik, penggunaan botol minum reusable dan pemanfaatan kardus bekas untuk wadah mainan atau untuk rak buku. 


\subsection{GOVERNMENT AND INFRASTRUCTURE (PEMERINTAH DAN INFRASTRUKTUR)}

Sub komponen pemerintahan dari hasil analisis skoring likert mendapat penilaian sangat baik dengan persentase sebesar $87,72 \%$. Penilaian berfokus pada peran pemerintah lokal dalam mewujudkan kampung minim sampah. Pemerintahan lokal di kampung Ngemplak Sutan merujuk pada pengurus RT dan RW. Peran pengurus RT dan RW selama ini memberikan sosialisasi dalam rapat rutin mengenai persampahan dan menggalang partisipasi masyarakat untuk kegiatan bersih kampung. Sosialisasi dilakukan dalam acara rapat rutin, biasanya disisipkan pada rangkaian acara rapat RT/RW. Kegiatan bersih kampung dilaksanakan sebulan sekali. Pemerintahan lokal juga biasanya yang mengkoordinir warga apabila ada kompetisi adipura atau kompetisi yang berkaitan dengan kampung sehat sehingga warga bisa bersama-sama menciptakan kampung yang bersih dan sehat.

Sub komponen selanjutnya adalah green waste community (komunitas sampah). Sub komponen komunitas lokal mendapatkan penilaian sangat baik dengan persentase pelaksanaan sebesar $86,90 \%$. Persentase tersebut dibuktikan dengan adanya organisasi pengelola sampah yang sampai saat ini masih aktif yaitu KSM Pengelola Sampah dan Bank Sampah Amanah. Walaupun dikarenakan agenda kampung yang padat dan juga agenda pribadi membuat kegiatan pengelolaan sampah terkadang tersendat. Organisasi lain yang berkaitan dengan pemberdayaan masyarakat kampung, yaitu ada Kelompok Wanita Tani Kahuripan Sejahtera dan Kelompok Masyarakat Kampung Sayur dan Kampung Iklim. Dua kelompok terakhir lebih fokus pada kegiatan bercocok tanam dan peternakan untuk mendukung visi Kampung Ngemplak Sutan sebagai Kampung Mandiri Pangan.

Infrastruktur persampahan di Kampung Ngemplak Sutan mendapatkan hasil penilaian 71,59\% yang berada dalam range baik. Hasil observasi dan fakta di kawasan menunjukkan kondisi dan ketersediaan fasilitas persampahan di antaranya ada tempat sampah individu, tempat sampah komunal, komposter individu, komposter komunal, alat pencacah, bangunan bank sampah, alat timbang dan gerobak pengangkut. Secara kuantitas didapatkan hasil, perlunya penambahan fasilitas, yaitu pada fasilitas tempat sampah individu yang hanya disediakan 1 wadah untuk setiap hunian. Seharusnya disediakan 2 wadah untuk memisahkan antara sampah organik dan anorganik. Bangunan bank sampah juga belum memadai karena menggunakan teras rumah warga untuk kegiatan penimbangan sampah. Lebih baik untuk menyediakan bangunan tersendiri agar memudahkan pengurus dalam melakukan pengumpulan sampah dan tidak mengganggu aktivitas warga lainnya. Komposter individu sudah mencukupi, namun pemanfaatan dari komposter individu belum maksimal. Komposter individu dibiarkan terbengkalai di halaman rumah dan tidak digunakan untuk daur ulang sampah organik. Peta persebaran sarana persampahan di Kampung Ngemplak Sutan ditunjukkan dalam Gambar 1.

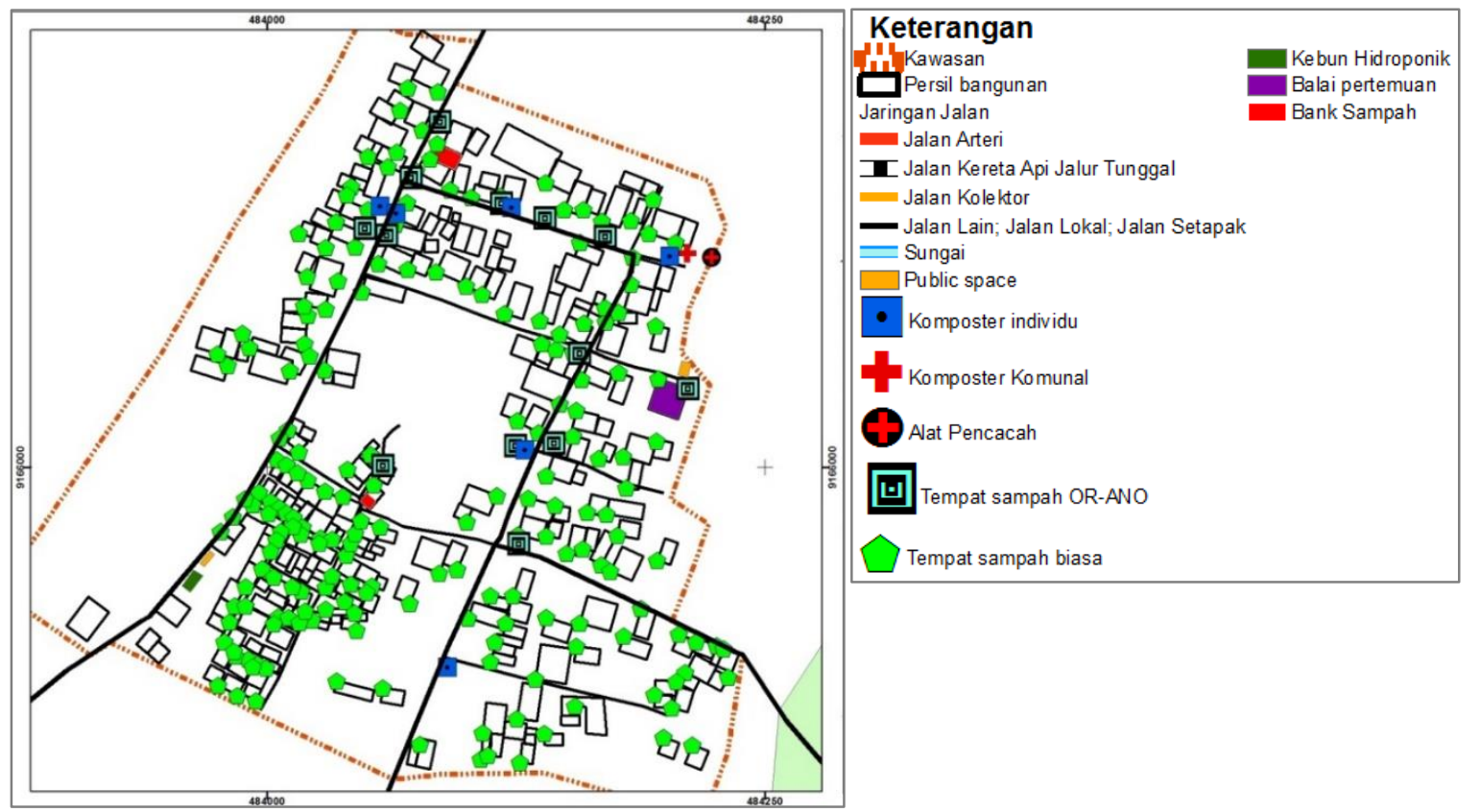

Gambar 1. Peta Persebaran Sarana Persampahan Kampung Ngemplak Sutan 


\subsection{MARKET CREATION (PENCIPTAAN PASAR)}

Penciptaan pasar persampahan di Kampung Ngemplak Sutan dapat dilihat dari pendapatan yang dihasilkan masyarakat pada usaha pengelolaan sampah, usaha lokal yang diciptakan oleh masyarakat terkait pengelolaan sampah dan target pasar yang telah dijangkau masyarakat. Hasil analisis skoring likert menunjukkan bahwa masyarakat menghasilkan tambahan pendapatan yang cukup menjanjikan karena penilaiannya masuk dalam range baik. Pendapatan yang masyarakat peroleh, yaitu dari penjualan sampah anorganik melalui bank sampah, penjualan barang hasil daur ulang, dan penjualan kompos. Keuangan hasil penjualan dikelola oleh organisasi pengelolaan sampah KSM Pengelola Sampah dan Bank Sampah. Analisis skoring untuk sub variabel ekonomi lokal menunjukkan hasil pada range baik dengan persentase pelaksanaan $63,35 \%$. Sebenarnya persentase realisasi usaha lokal bisa lebih meningkat apabila aspek target konsumen dari produk sampah juga mendapatkan penilaian yang tinggi. Namun target konsumen hanya mendapatkan persentase sebesar $59 \%$ karena memang target konsumen dari produk-produk sampah Kampung Ngemplak Sutan selama ini hanya berada dalam lingkup masyarakat kampung dan sekitar kampung serta dinas-dinas terkait yang memberikan pembinaan persampahan pada masyarakat.

\subsection{EVALUASI KONSEP ZERO WASTE KAMPUNG NGEMPLAK SUTAN RW 37, MOJOSONGO}

Hasil analisis skoring likert menunjukkan bahwa konsep zero waste di Kampung Ngemplak Sutan RW 37 sudah dilaksanakan sejauh 64,49\% (Gambar 2). Pencapaian persentase tersebut didukung dan dipengaruhi oleh hasil evaluasi dari komponen utama yang dijalankan di kawasan. Komponen tersebut, yaitu kebijakan terkait persampahan, sumber daya manusia, dan infrastruktur.

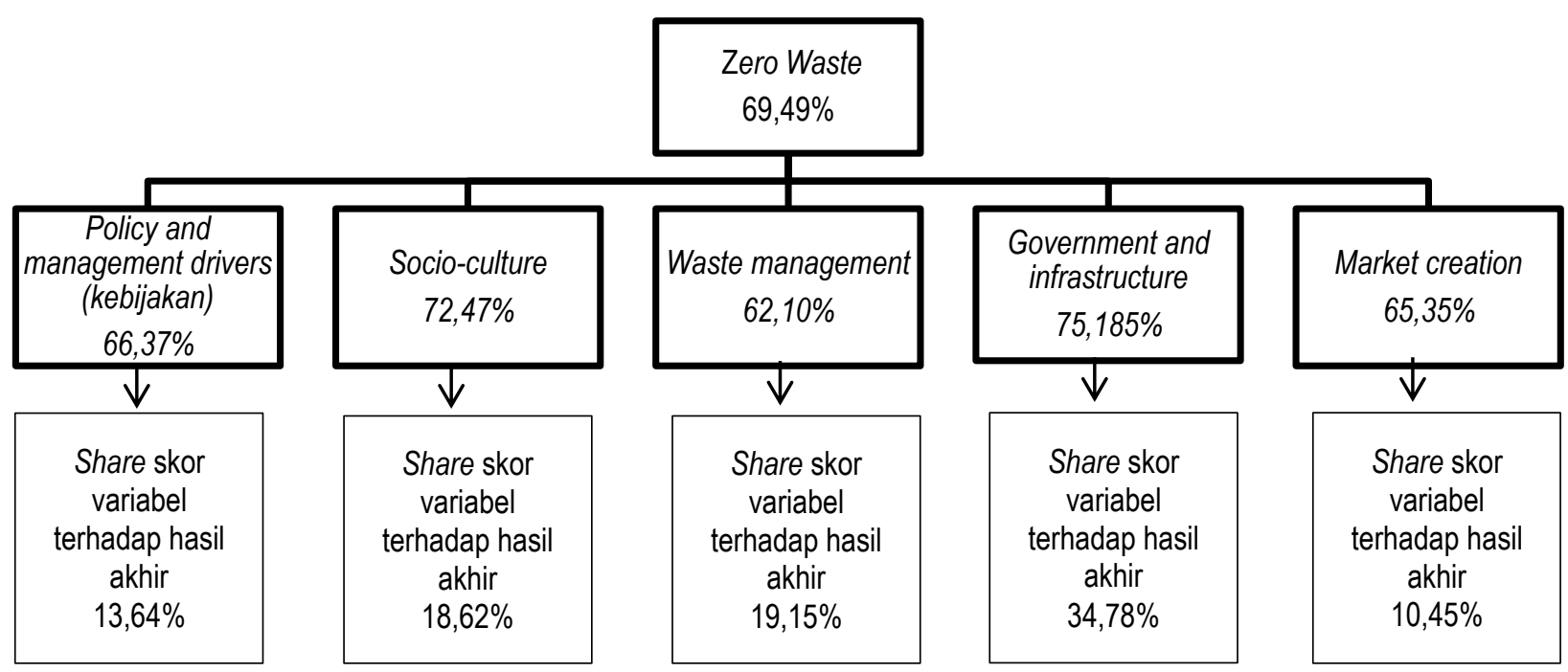

Gambar 2. Bagan Komponen Zero Waste yang Mempengaruhi Hasil Evaluasi Akhir

Hasil evaluasi dari kebijakan yang sudah diaplikasikan di Kampung Ngemplak Sutan menunjukkan persentase 66,37\% dengan share skor sebesar 13,64\%. Regulasi/kebijakan yang dibuat pemerintah merupakan bentuk pelayanan pemerintah kepada masyarakat. Perwujudan kebijakan berupa peraturan perundangan dan peraturan lingkungan. Peraturan perundangan atau peraturan lingkungan perlu adanya kesadaran dan pengetahuan dari masyarakat untuk menegakkan peraturan tersebut. Kesadaran untuk menegakkan peraturan akan sangat membantu pengelolaan persampahan kawasan (Mulasari, dkk., 2014). Kesadaran masyarakat tumbuh dari bekal keilmuan dan pengetahuan. Kesadaran yang tumbuh pada masyarakat akan mempengaruhi pola perilaku dan budaya masyarakat. Maka dari itu, kebijakan dan sumber daya manusia ada pada stagel posisi yang sama dalam pengaruh penerapan konsep zero waste di Kampung Ngemplak Sutan.

Hasil evaluasi dari kebijakan yang sudah diaplikasikan di Kampung Ngemplak Sutan menunjukkan persentase 66,37\% yang kemudian dalam proporsi pengaruh terhadap hasil akhir, yaitu berpengaruh sebesar $13,64 \%$. Regulasi/kebijakan yang dibuat pemerintah merupakan bentuk pelayanan pemerintah kepada masyarakat. Perwujudan kebijakan berupa peraturan perundangan dan peraturan lingkungan. Peraturan perundangan atau peraturan lingkungan perlu adanya kesadaran dan 
pengetahuan dari masyarakat untuk menegakkan peraturan tersebut. Kesadaran untuk menegakkan peraturan akan sangat membantu pengelolaan persampahan kawasan (Mulasari,dkk., 2014). Kemudian posisi kedua komponen yang mempengaruhi hasil akhir, yaitu penyederhanaan komponen SDM. Persentase didapatkan dari rata-rata hasil 3 komponen (sosio-kultural, manajemen persampahan, dan penciptaan pasar), yaitu sebesar $16,73 \%$.

Infrastruktur menempati posisi pertama untuk komponen yang berpengaruh besar pada progress penerapan konsep zero waste di kampung Ngemplak Sutan. Hasil proporsi pengaruh terhadap hasil akhir adalah sebesar 34,78\%. Hasil tersebut didukung pula penjabaran dalam Modul Sampah 3R dari DPU yang mencantumkan proses identifikasi sarana dan prasarana persampahan ada pada tahap pertama, yaitu tahap persiapan pengelolaan sampah perumahan permukiman. Proses identifikasi infrastruktur diutamakan untuk dilakukan terlebih dahulu mengindikasikan bahwa infrastruktur persampahan memegang peranan yang sangat penting dalam pengelolaan sampah.

\section{KESIMPULAN}

Penerapan konsep zero waste di Kampung Ngemplak Sutan sudah berjalan sejauh 67,78\% yang dipengaruhi oleh realisasi dari setiap komponen zero waste. Dapat dilihat dari analisis skoring likert masing-masing komponen yang didasarkan pada persepsi masyarakat sebagai pelaksana pengelolaan sampah, yang mana komponen yang memiliki pengaruh paling besar terhadap hasil akhir, yaitu komponen policy (kebijakan), infrastructure (infrastruktur), dan SDM. Komponen kebijakan telah dilaksanakan $66,37 \%$ dengan poin utama pelaksanaan, yaitu pembuatan kebijakan atau aturan lingkungan mengenai pengelolaan sampah dan pemahaman kepada masyarakat atas aturan/kebijakan pengelolaan sampah. Pengaruh terhadap hasil akhir, yaitu sebesar $13,64 \%$. Komponen yang berpengaruh pada posisi kedua, yaitu komponen SDM dengan proporsi pengaruh terhadap hasil evaluasi sebesar $16,73 \%$. Komponen SDM yang terpecah menjadi beberapa variabel di antaranya sosio-kultural, penciptaan pasar oleh masyarakat dan manajemen pengelolaan sampah. Komponen infrastruktur memberikan persentase terbesar dalam mempengaruhi progress penerapan konsep zero waste. Persentase proporsi pengaruh komponen infrastruktur, yaitu sebesar $34,78 \%$ terhadap persentase keseluruhan. Hal ini juga ternyata sesuai dengan teori dalam modul sampah 3R (2010) dalam bagian tata cara pengelolaan sampah perumahan secara partisipatif, identifikasi fasilitas persampahan menempati urutan pertama dalam pengelolaan persampahan. Maka dari itu, perlu dipahami bahwa infrastruktur, SDM, dan kebijakan merupakan tiga komponen penting yang harus diperhatikan apabila ingin memulai menerapkan konsep zero waste di suatu kawasan. Tetapi tidak berarti kita dapat mengesampingkan sub komponen lain, seperti potensi ekonomi dan kelembagan, karena kedua hal tersebut juga akan mempengaruhi keberhasilan penerapan zero waste.

\section{DAFTAR PUSTAKA}

Abriyani, A. (2016). PENGELOLAAN SAMPAH SOLO : TPA Putri Cempo Sudah Overload Sejak 10 Tahun Lalu, dari Solopos.com. Diakses dari https://www.solopos.com/pengelolaan-sampah-solo-tpa-putri-cempo-sudah-overload-sejak-10-tahun-lalu-720984

Andimuhtarom, I. (2017, Maret 12). PENGELOLAAN SAMPAH SOLO : Volume Sampah TPA Putri Cempo Naik Hingga 20 Ton Per Hari, dari Solopos.com. Diakses dari https://www.solopos.com/pengelolaan-sampah-solo-volume-sampah-tpa-putri-cempo-naik-hingga20-ton-per-hari-800797

Damanhuri, E, \& Padmi, T (2008). Diktat Kuliah Pengelolaan Sampah. Bandung: FTSL ITB.

Kementerian Pekerjaan Umum. (2010). Modul Sampah Berbasis 3R. Bandung. Diakses dari http://litbang.pu.go.id/puskim/source/pdf/Modul\%20Sampah\%203R.pdf

Kholil. (2005). Rekayasa Model Sistem Dinamika Pengelolaan Sampah Terpadu Berbasis Nir Limbah (Zero State). Tesis. Sekolah Pasca Sarjana Institut Pertanian Bogor.

Krisnani, H. (2017). Perubahan Pola Pikir Masyarakat Mengenai Sampah Melalui Pengolahan Sampah Organik dan Non-Organik di Desa Genteng, Kecamatan Sukasari, Kabupaten Sumedang. Prosiding Penelitian dan Pengabdian Kepada Masyarakat, 4(2), 281-289. Diakses dari http://jurnal.unpad.ac.id/prosiding/article/view/14345/6925

Mukhlis, \& Luthfi, M. (2010). Hukum Administrasi Lingkungan Kontemporer. Malang: Setara Press.

Mulasari, S.A., Husodo, A.H., \& Muhadjir, N. (2014). Kebijakan Pemerintah dalam Pengelolaan Sampah Domestik. Kesmas. Jurnal Kesmas, 8(8), 1-7. DOI: 10.21109/kesmas.v8i8.412

Nizar, M. Munir, E., Munawar E., \& Irvan (2017). Manajemen Pengelolaan Sampah Kota Berdasarkan Konsep Zero Waste : Studi Literatur. Jurnal Serambi Engineerig, 1(2). Diakses dari http://ojs.serambimekkah.ac.id/index.php/jse/article/view/500

Palgunadi, B. (2008). Disain Produk 3: Aspek-aspek Disain. Bandung : Penerbit ITB. 
Desa-Kota, Vol. 3, No. 1, 2021, 49-60

Purnamayani, R., \& Edi, S. (2011). Alternatif Teknologi Pengomposan Berbahan Baku Sampah Perkotaan Untuk Mendukung Pertanian Organik di Kota Jambi. BPTP Balitbang Jambi. Diakses dari http://jambi.litbang.pertanian.go.id/ind/images/PDF/rima3.pdf

Sejati, K. (2009). Pengolahan Sampah Terpadu. Yogyakarta: Kanisius

SNI Nomor 2454 Tahun 2002 tentang Operasional Pengelolaan Sampah. Diakses dari http://ciptakarya.pu.go.id/plp/upload/peraturan/SNI_19-2454-

2002_Tata_Cara_Teknik_Operasional_Pengelolaan_Sampah_Perkotaan.pdf

SNI Nomor 3242Tahun 2008 tentang Pengelolaan Sampah Diakses dari http://sni.litbang.pu.go.id/index.php?r=/sni/new/sni/detail/id/764

Soekanto, S. (1983). Faktor-faktor Yang Mempengaruhi Penegakan Hukum. Jakarta : PT Raja Grafindo Persada.

Suprapto. (2016). Peran Daur Ulang untuk Meningkatkan Pengelolaan Sampah Terpadu di Surabaya. Jurnal Pusat Teknologi Lingkungan, 9(2), 127-142. Diakses dari http://ejurnal.bppt.go.id/index.php/JRL/article/download/1999/1695

Suyanto, E., dkk. (2015). Model Kebijakan Pengelolaan Sampah Berbasis Partisipasi "Green Community" Mendukung Kota Hijau. Mimbar Jurnal Sosial dan Pembangunan, 31(1), 143-152. Diakses dari https://ejournal.unisba.ac.id/index.php/mimbar/article/view/1295

Wahmuda, F., \& Puspitasari, R. (2015). Pengembangan Desain Produk Dari Tongkol Jagung Berbasis Industri Kreatif. Seminar Nasional Sains dan Teknologi Terapan III, Institut Teknologi Adhi Tama Surabaya, 627-636. Diakses dari https://www.researchgate.net/publication/321746764_PENGEMBANGAN_DESAIN_PRODUK_DARI_TONGKOL_JAGUNG_BER BASIS_INDUSTRI_KREATIF

Zaman, A.U., \& Lehmann, S. (2013). The Zero waste Index : Measuring The Performance of Zero waste City. Jurnal of Cleaner Production, 50(1), 123-132. DOI: 10.1016/j.jclepro.2012.11.041 